\title{
Pengaruh Orientasi Pasar Dan Orientasi Kewirausahaan Terhadap Kinerja UMKM Di Jakarta Barat
}

\author{
Harry Darwis dan Louis Utama \\ Program Studi S1 Manajemen Fakultas Ekonomi dan Bisnis \\ Universitas Tarumanagara, Jakarta \\ Email: harrydarwis@gmail.com
}

\begin{abstract}
Purpose - The purpose of this paper is to investigate the impact of market orientation (MO) and entrepreneurial orientation (EO) on business performance among small retailers. In particular, the goal is to understand and determine to what extent MO and EO influence firm performance directly, and to what extent $M O$ and EO are connected to performance. Design/methodology/approach - The developed conceptual model is tested using partial least square ( PLS ) using a sample of 30 small retailers. Findings The result of the PLS model shows that both MO and EO act as a basis for improved business performance among small retailers. Based on the research findings, it can be argued that both $M O$ and EO fully unlock their value-creating potential among small retail firms. Originality/value - This study has provided new insights regarding the impact of $M O$ and EO on business performance in the context of small retail firms. In particular, the study has contributed to the literature by demonstrating the routes through which MO and EO impact on performance.
\end{abstract}

Keywords: Business performance, Retailing, Entrepreneurial orientation, Market orientation, Small retailers, Impact of MO and EO Paper type Research paper

\begin{abstract}
Abstrak: Tujuan - Tujuan dari makalah ini adalah untuk menyelidiki dampak orientasi pasar (MO) dan orientasi kewirausahaan (EO) pada kinerja bisnis di antara pengecer kecil. Secara khusus, tujuannya adalah untuk memahami dan menentukan sejauh mana MO dan EO mempengaruhi kinerja perusahaan secara langsung, dan sejauh mana MO dan EO terhubung dengan kinerja. Desain / metodologi / pendekatan - Model konseptual yang dikembangkan diuji menggunakan partial least square (PLS) menggunakan sampel 30 pengecer kecil. Temuan - Hasil model PLS menunjukkan bahwa baik MO dan EO bertindak sebagai dasar untuk meningkatkan kinerja bisnis di antara pengecer kecil. Berdasarkan temuan penelitian, dapat dikatakan bahwa MO dan EO sepenuhnya membuka kunci potensi penciptaan nilai mereka di antara perusahaan ritel kecil. Orisinalitas / nilai Studi ini telah memberikan wawasan baru mengenai dampak MO dan EO pada kinerja bisnis dalam konteks perusahaan ritel kecil. Secara khusus, penelitian ini telah berkontribusi pada literatur dengan menunjukkan rute melalui mana $\mathrm{MO}$ dan $\mathrm{EO}$ berdampak pada kinerja.
\end{abstract}

Kata kunci: Business performance, Retailing, Entrepreneurial orientation, Market orientation, Small retailers, Impact of MO and EO Paper type Research paper. 


\section{LATAR BELAKANG}

Usaha mikro kecil dan menengah memiliki peran penting dalam kehidupan masyarakat, khususnya sangat berperan penting sebagai penopang dalam kemajuan dan perkembangan perkonomian negara Indonesia. Hal ini tentunya memberikan perubahan akan terjadinya pertumbuhan peluang kerja yang baru, membuka peluang pasar, serta menciptakan pertumbuhan pada usaha dalam berbagai sektor.

Perkembangan dunia usaha sekarang ini ditandai dengan semakin banyaknya pelaku usaha dalam berbagai bidang yang membentuk semakin tajamnya persaingan, hal itu dapat dirasakan pada usaha mikro kecil dan menengah pada bidang bisnis yang melibatkan para pelaku bisnis agar dapat bersaing di tengah lingkungan bisnis yang dinamis dalam hal menarik minat konsumen ditengah persaingan untuk dapat menjaga kelangsungan hidup usaha sehingga dapat bersaing, untuk itu diperlukan adanya evaluasi kembali apa yang menjadi bagian kelemahannya dan apa yang perlu ditambahkan sehingga dapat meningkatkan kinerja dan strategi mereka oleh karena tekanan dalam persaingan bisnis yang mempengaruhi unit usaha mikro kecil dan menengah. Kondisi persaingan pasar yang kompetitif juga merupakan aspek yang tidak terlepas dari fokus oleh karena harus bersaing untuk dapat diminati lebih oleh pasar. Tetapi, dalam kenyataannya tuntutan yang dihadapi dari lingkungan bisnis saat ini masih terasa sulit untuk dipenuhi oleh usaha mikro kecil dan menengah dan masih banyak yang jatuh bangun dalam bisnis.

Usaha mikro kecil dan menengah yang secara kualitas dapat menghambat pertumbuhannya oleh karena dihadapi oleh beberapa masalah dalam hal kinerja. Penurunan pada kinerja dapat disebabkan oleh permasalahan pada kelemahan untuk merespon pasar. Kinerja melibatkan peranan yang penting dalam mengetahui kondisi suatu usaha, maka diperlukan pemahaman yang lebih baik akan pentingnya apa yang diminati oleh pasar agar dapat terciptanya nilai yang layak serta nilai yang diciptakan agar mampu bersaing dengan para pesaing pesaing lainnya. Walaupun UMKM memiliki kemampuan untuk mengumpulkan sumber daya yang berharga, itu tidak menjamin akan tercapainya keunggulan kompetitif dipasar yang bergejolak. Hal ini dikarenakan kemampuan untuk mengenali peluang dan nilai penting dipasar yang cepat berubah, keunggulan kompetitif dibuat dari cara UMKM secara efektif bagaimana mengeksploitasi sumber daya (Utama, 2018).

Menurut (Knight, 2000) dengan sumber daya yang secara relatif masih terbatas dan kurangnya kapabilitas UMKM harus memiliki orientasi kewirausahaan agar tetap dapat bertahan dalam bisnis mereka untuk tetap unggul jika dibandingkan dengan kompetitor mereka. Agar usaha kecil dan menengah tetap mempertahankan usahanya, perlu untuk mengembangkan kemampuan pengetahuan kewirausahaan, Dalam berwirausaha ada beberapa hal yang menentukan keberhasilan tidaknya suatu usaha yang dijalankan. Yang pertama adalah orientasi kewirausahaan. Orientasi kewirausahaan telah menjadi konsep dominan dalam bidang penelitian kewirausahaan dimana mengacu pada orientasi strategis perusahaan berdasarkan pada proses dan perilaku wirausaha yang spesifik, serta menggambarkan bagaimana perusahaan menemukan dan memanfaatkan peluang baru jauh didepan para pesaing (Utama, 2018).

secara spesifik orientasi kewirausahaan (entrepreneurial orientation) merupakan kemampuan yang dimiliki seorang entrepreneur yang dijadikan dasar untuk mencari peluang menuju kesuksesan. Orientasi kewirausahaan merupakan suatu hal yang penting 
yang berguna untuk meningkatkan kompetisi dan kinerja perusahaan (Zahra \& Covin, 1995).

Orientasi kewirausahaan mengacu pada orientasi strategis perusahaan dan kemampuannya untuk menangkap aspek kewirausahaan tertentu dari gaya pembuatan keputusan, metode dan praktik (Wiklund \& Shepherd, 2005). Selain itu, Orientasi kewirausahaan merupakan suatu keadaaan yang berkecenderungan individunya untuk melakukan inovasi, proaktif dan mau mengambil risiko untuk memulai atau mengelola suatu usaha (Knight, 2000).

Selain itu, agar mendapat pemahaman yang lebih baik maka suatu usaha perlu memiliki orientasi pasar karena dengan itu dapat membuat perusahaan lebih unggul jika dibanding dengan yang tidak adanya orientasi pasar. Orientasi pasar merupakan budaya organisasi yang paling efektif dan efisien untuk menciptakan perilaku-perilaku yang dapat menghasilkan suatu yang terbaik bagi pembeli serta menghasilkan superior performance bagi perusahaan (Narver \& Slater, 1990) .Orientasi pasar merupakan suatu budaya bisnis yang menghasilkan kinerja dengan menciptakan nilai pelanggan (Narver, Slater, \& Maclachlan, 2000). Selain itu, Orientasi pasar menempatkan prioritas tertinggi untuk tetap dapat dekat dengan pasar dan menciptakan nilai pelanggan yang unggul (Ngo \& O'Cass, 2012).

Orientasi pasar mencerminkan derajat untuk membuat keputusan dalam perusahaan didorong oleh pelanggan dan pesaing (Jaworski \& Kohli, 1993) . Orientasi pasar merupakan salah satu faktor yang tidak berwujud yang bedampak bagi kinerja perusahaan (Homburg, Krohmer, \& Workman, 2003). Orientasi pasar memiliki tiga dimensi yaitu orientasi pelanggan, orientasi pesaing dan koordinasi antar fungsi (Zhou et al., 2005). Tanpa hadirnya orientasi pasar di usaha kecil dan menengah implikasinya berupa terhambatnya Pertumbuhan usaha dan sulit untuk mencipatakan nilai unggul dari pelanggan, serta tidak dapat peka terhadap strategi pesaing yang dihadapi sehingga berpengaruh pada kinerja usaha.

Mengingat usaha mikro kecil dan menengah memiliki peran dalam penggerak perekonomian, salah satunya yang dapat dilihat dalam persaingan bisnis kuliner yang melibatkan rantai bisnisnya dan membentuk pangsa pasar masing masing serta persaingan antar bidang kuliner yang semakin dinamis. Maka peneliti memfokuskan penelitian ini terhadap bisnis kuliner.

\section{KAJIAN TEORI}

Orientasi Pasar. Menurut Kohli \& Jaworski (1990) orientasi pasar sebagai generasi organisasi yang luas akan inteligen pasar yang berkaitan dengan kebutuhan pelanggan saat ini dan masa depan, penyebaran kecerdasan dalam suatu organisasi dan responsif terhadapnya. Orientasi pasar berdasarkan definisi Narver \& Slater (1990) yaitu budaya organisasi yang paling efektif dan efisien dalam menyatakan perilaku yang diperlukan untuk penciptaan nilai unggul bagi pembeli dan juga unggul dalam kinerja dalam bisnis. Terdapat beberapa komponen dalam orientasi pasar Menurut Narver \& Slater (1990) yaitu orientasi pasar terdiri dari tiga komponen perilaku yaitu orientasi pelanggan, orientasi pesaing, dan koordinasi antar-fungsional. Orientasi pelanggan mengacu pada kemampuan perusahaan dalam menciptakan nilai yang sangat baik bagi pelanggan dan memahami jaringan suply chain Narver \& Slater (1990). Day \& Wensley (1988) Orientasi pesaing didefinisikan sebagai kemampuan perusahaan dalam mengidentifikasikan kekuatan, 
kelemahan, kemampuan jangka panjang dan strategi untuk mendapatkan daya saing pasar. Narver, Slater, \& MacLachlan (2004) Koordinasi interfunctional mengacu pada kemampuan perusahaan dalam menciptakan nilai lebih target pelanggan. Berdasarkan uraian tentang orientasi pasar tersebut, dapat disimpulkan bahwa orientasi pasar merupakan suatu proses untuk memperoleh, menerapkan, dan menyebarkan informasi untuk memenuhi keinginan serta kebutuhan konsumen dan mengetahui perilaku pesaing serta orientasi pasar memiliki kecenderungan agar individu untuk tetap dekat dengan pasar pesaing, pelanggan, dan koordinasi antar fungsional sehingga dapat meningkatkan kepuasan pelanggan agar dapat menciptakan keunggulan bersaing dan meningkatkan kinerja perusahaan.

Orientasi kewirausahaan. Menurut Morris \& Paul (1987) mendefinisikan orientasi kewirausahaan merupakan kecenderungan manajemen puncak untuk mengambil resiko yang telah diperhitungkan, inovatif, dan untuk menunjukkan proaktif. Ginsberg (2011) memberi pengertian orientasi kewirausahaan memiliki kecenderungan individu untuk melakukan inovasi, proaktif, dan pengambilan resiko dengan tujuan untuk menjalankan usaha. Menurut Walter dan Ritter (2006) orientasi kewirausahaan sebagai alat yang digunakan untuk mengukur sejauh mana manajer dari suatu perusahaan melakukan tindakan yang inovatif, proaktif, dan berani mengambil risiko dalam membuat suatu keputusan strategis. Inovatif menjadi suatu kecenderungan untuk mendukung dalam hal menciptakan ide-ide baru,eksperimen, dan proses kreatif, yang berangkat dari praktik yang telah siap dan dengan menggunakan bantuan teknologi. Miller \& Friesen (1978) Pengambilan risiko dikaitkan dengan kemauan untuk melakukan sejumlah besar sumber daya untuk proyek-proyek di mana biaya resiko kegagalan yang kemungkinan tinggi. Lumpkin dan Dess (1996) Lumpkin dan Dess (1996) Proaktif mengacu pada harapan perubahan atau peluang di masa depan. Berdasarkan uraian tentang orientasi kewirausahaan tersebut, maka dapat disimpulkan bahwa orientasi kewirausahaan memiliki kecenderungan pada individu untuk memiliki kemampuan berinovasi, proaktif, dan pengambilan resiko yang bertujuan untuk menjalankan usaha sehingga mampu untuk membentuk dan menjalankan strategi dan memiliki keunggulan yang kompetitif.

Kinerja. Menurut Mulyadi (2009), kinerja adalah hasil dari keberhasilan dalam mewujudkan sasaran strategik perusahaan dan membuat sasaran strategik perusahaan ini menjadi hasil yang dapat membuat keberhasilanya misi, visi, keyakinan dasar, nilai dasar, dan strategi perusahaan.

Lalu definisi kinerja menurut Morgan (2003), kinerja sebagai sebuah proses dari hasil kerja atas kemampuan untuk mengelola sumber daya. Konteks pengertian kinerja menurut Tangkilisan (2005) adalah suatu keadaan yang berkaitan dengan keberhasilan organisasi dalam menjalankan misi yang dimilikinya yang dapat diukur dari tingkat produktivitas, kualitas layanan, responsivitas, responsibilitas, dan akuntabilitas. Definisi kinerja menurut Chaizi Nasucha (2004) bahwa kinerja adalah suatu organisasi yang membuat keadaan efektivitas dalam organisasi itu tersebut secara menyeluruh untuk memenuhi kebutuhan yang ditetapkan dari setiap kelompok yang berkenaan dengan usaha usaha yang sistematik dan meningkatkan kemampuan organisasi secara terus menerus hingga mencapai kebutuhannya secara efektif. Berdasarkan uraian tentang orientasi 
kewirausahaan tersebut, maka dapat disimpulkan bahwa kinerja merupakan keadaan yang berkaitan dengan kemampuan suatu organisasi untuk dapat meningkatkan kemampuannya terus menerus sehingga dapat tercapainya keberhasilan secara efektif.

Kaitan Antara Variabel Orientasi Pasar Terhadap Kinerja Usaha. Dalam konteks kewirausahaan Morgan (2009) menyatakan bahwa orientasi pasar secara positif mempengaruhi kinerja usaha. Misalnya oleh (kirca, 2005) merangkum secara empiris temuan dari literatur Orientasi Pasar memiliki dampak positif terhadap kinerja. Selain itu, terdapat penelitian di antara perusahaan kecil dan menengah telah mengkonfirmasi hubungan positif antara Orientasi Pasar dan kinerja (Pelham, 2000). Sehubungan dengan sebagian studi tentang Orientasi Pasar telah berfokus pada bidang manufaktur, tetapi terdapat juga beberapa studi tentang Orientasi Pasar di industri ritel (Panigyrakis dan Theodoridis, 2007). Panigyrakis dan Theodoridis (2007) menunjukkan efek positif yang kuat dari Orientasi Pasar terhadap kinerja ritel, baik secara finansial maupun non-finansial. Sama halnya Chen dan Quester (2006) juga menunjukkan bahwa Orientasi Pasar meningkatkan loyalitas pelanggan di sektor ritel. Sedemikian Juga halnya dengan penelitian yang dilakukan oleh Megicks dan Warnaby (2008) menunjukkan bahwa Orientasi Pasar dan kinerja terkait positif dalam konteks pengecer berukuran kecil.

Kaitan Antara Orientasi Kewirausahaan Terhadap Kinerja Usaha. Dalam konteks kewirausahaan Lumpkin dan Dess (1996) menunjukan bahwa orientasi kewirausahaan berkontribusi pada kinerja perusahaan. Selain itu, Temuan dari studi yang dilakukan oleh Keh (2007) menunjukkan bahwa tingkat orientasi kewirausahaan dapat memberikan efek langsung dan tidak langsung pada kinerja perusahaan. Smart and Conant (1994) mengidentifikasi bahwa orientasi kewirausahaan dan organisasi kinerja secara signifikan terkait di sektor ritel. Ada juga bukti terbaru dari dampak positif yang relatif kuat dari orientasi kewirausahaan pada kinerja bisnis dari layanan sektor secara umum (Kraus, 2013). Namun, telah diperdebatkan bahwa efek orientasi kewirausahaan pada kinerja mungkin berbeda dalam berbagai jenis lingkungan (Wiklund dan Shepherd, 2005). Penelitian tentang kinerja perusahaan kecil juga telah mengakui pentingnya orientasi kewirausahaan memiliki kinerja positif. Sebagai contoh, (Wiklund \& Shepherd, 2005) telah menemukan bahwa adanya orientasi kewirausahaan secara positif mempengaruhi kinerja usaha kecil. (Wiklund dan Shepherd, 2005) merangkum temuan mereka sebagai berikut "it appears relatively safe to say that EO generally contributes to improved performance". Dalam pernyataan ini menyatakan bahwa tampaknya relatif aman untuk dikatakan bahwa orientasi kewirausahaan secara umum berkontribusi pada peningkatan kinerja.

Kerangka Pemikiran dan Hipotesis. Brand awareness adalah kemampuan konsumen untuk mengingat dan mengenali suatu merek dalam kondisi yang berbeda didalam ingatan mereka.. eWOM adalah tindakan yang dilakukan seseorang untuk berbagi pendapat / informasi mengenai suatu pengalaman mereka terhadap sebuah brand kepada orang lain melalui media elektronik. Brand loyalty adalah loyalitas konsumen terhadap suatu merek yang tidak dapat tergantikan dikepala mereka oleh merek-merek lainnya. Berdasarkan uraian sebelumnya maka dapat digambarkan kerangka pemikiran sebagai berikut: 


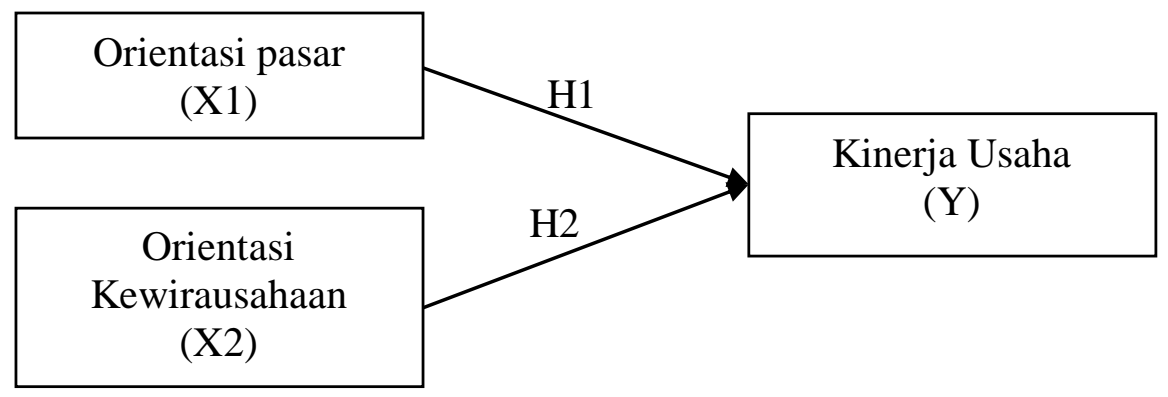

Gambar 2.1. Model Kerangka Pemikiran

Berdasarkan Gambar 2.1, maka hipotesis yang ada dalam penelitian ini adalah sebagai berikut:

H1 : Orientasi pasar berpengaruh terhadap kinerja usaha mikro kecil dan menengah pada usaha Kuliner di Jelambar, Jakarta Barat.

H2 : Orientasi kewirausahaan berpegaruh pengaruh terhadap kinerja usaha mikro kecil dan menengah pada usaha Kuliner di Jelambar, Jakarta Barat.

\section{METODOLOGI}

Desain penelitian memberikan prosedur untuk mendapat informasi informasi yang diperlukan untuk menyusun atau menyelesaikan suatu masalah dalam penelitian, suatu desain penelitian dapat didefinisikan dalam pengertian yang sempit dan pengertian yang luas. Dalam pengertian yang sempit suatu desain penelitian sendiri merupakan rincian dari seluruh prosedur perolehan dan penganalisaan data empiris yang mencakup pada penentuan subjek, pengembangan instrumen untuk memperoleh data empiris, perolehan data, persiapan analisis ,serta analisis data. Sedangkan dalam arti luas desain penelitian adalah desain yang mencangkup semua rencana pelaksanaan penelitian, mulai dari adanya permasalahan sampai kegiatan yang paling terakhir dari sebuah penelitian (Aritonang, 2007).

Desain penelitian memiliki fungsi untuk menjelaskan dasar penelitian secara rinci yang diperlukan untuk dapat menyelesaikan masalah dalam suatu penelitian. Pendekatan yang dipakai dalam penelitian ini adalah pendekatan kuantitatif. Menurut Sugiyono (2007), metode penelitian kuantitatif didefinisikan sebagai sebuah metode penelitian yang berlandaskan pada filsafat positivisme, yang digunakan untuk meneliti suatu populasi atau sampel tertentu dengan teknik pengambilan sampel yang pada umumnya dilakukan secara acak, pengumpulan data dilakukan dengan menggunakan analisis data bersifat kuantitatif atau statistik dengan tujuan untuk menguji hipotesis yang telah ditentukan, kemudian, pada desain penelitian yang digunakan dalam penelitian ini adalah penelitian konklusif 


\section{HASIL DAN PEMBAHASAN}

Hasil Analisis Data. Deskripsi subjek penelitian dari 30 responden. Berdasarkan karakteristik jabatan sebanyak 30 responden merupakan pemilik usaha kuliner. Berdasarkan karakteristik umur usaha Sebanyak 2 responden atau setara dengan $7 \%$ baru saja menjalankan bisnis kuliner kurang dari 1 tahun. Sebanyak 9 responden atau setara dengan 30\% telah menjalani bisnis kuliner dalam jangka waktu antara 1 sampai dengan 5 tahun. Lalu sebanyak 19 responden atau setara dengan 63\% telah menjalani bisnis kuliner dalam jangka waktu lebih dari 5 tahun. Berdasarkan karakteristik usia pemilik bisnis Sebanyak 2 responden atau setara dengan 7\% merupakan pemilik usaha berusia 21-30 tahun. Sebanyak 7 responden atau setara dengan 23\% merupakan pemilik usaha berusia 31-40 tahun. Lalu sebanyak 15 responden atau setara dengan 50\% merupakan pemilik usaha berusia 41-50 tahun. Sebanyak 4 responden atau setara dengan 13\% merupakan pemilik usaha berusia 51-60 tahun. Sebanyak 2 responden atau setara dengan 7\% merupakan pemilik usaha berusia $\geq 61$ tahun. Berdasarkan karakteristik jenis kelamin Sebanyak 15 responden atau setara dengan 50\% memiliki Jenis Kelamin Pria. Sebanyak 15 responden atau setara dengan 50\% memiliki Jenis Kelamin Wanita. Berdasarkan karakteristik jumlah karyawan Sebanyak 17 responden atau setara dengan 80\% memiliki jumlah karyawan berkisar antara 1 sampai dengan 4 orang. Sedangkan, sebanyak 3 responden atau setara dengan 20\% memiliki jumlah karyawan berkisar antara 5 sampai dengan 19 orang. sebanyak 0 responden memiliki jumlah karyawan berkisar antara 20 sampai dengan 99 orang. Lalu sebanyak 0 responden memiliki jumlah karyawan berkisar lebih dari 100 orang. Berdasarkan karakteristik omset penjualan Sebanyak 28 responden atau setara dengan 93\% memiliki omset penjualan selama setahun sebesar Rp 50 Juta - Rp 300 Juta. Sebanyak 2 Pemilik atau setara dengan 7\% memiliki omset penjualan selama setahun sebesar Rp 300 Juta - Rp 2,5 Milyar. Sebanyak 0 Pemilik atau setara dengan 0\% memiliki omset penjualan selama setahun sebesar Rp 2,5 Milyar - Rp 50 Milyar. Sebanyak 0 Pemilik atau setara dengan $0 \%$ memiliki omset penjualan selama setahun sebesar $>$ Rp 50 Milyar.

Tabel 4.1. Tanggapan Responden Atas Orientasi Pasar 
Darwis dan Utama: Pengaruh Orientasi Pasar Dan Orientasi Kewirausahaan...

\begin{tabular}{|c|c|c|c|c|c|c|c|}
\hline \multirow{3}{*}{ No } & \multirow{3}{*}{ Pernyataan } & STS & $\mathrm{TS}$ & $\mathrm{N}$ & S & SS & \multirow{3}{*}{$\begin{array}{l}\text { Rata-Rata } \\
\text { Jawaban }\end{array}$} \\
\hline & & \multicolumn{5}{|c|}{ BOBOT } & \\
\hline & & 1 & 2 & 3 & 4 & 5 & \\
\hline 1 & $\begin{array}{l}\text { Kami mampu merespons dengan cepat } \\
\text { tindakan pesaing kami }\end{array}$ & 0 & 3 & 6 & 15 & 6 & 3,8 \\
\hline 2 & $\begin{array}{l}\text { Aktivitas kompetitif kami didorong oleh } \\
\text { penciptaan kepuasan pelanggan }\end{array}$ & 0 & 0 & 4 & 15 & 11 & 4,23 \\
\hline 3 & $\begin{array}{l}\text { Kami sering menilai kepuasan } \\
\text { pelanggan }\end{array}$ & 0 & 3 & 8 & 13 & 6 & 3,73 \\
\hline 4 & $\begin{array}{l}\text { Kami secara aktif menilai perilaku } \\
\text { pesaing kami }\end{array}$ & 0 & 3 & 15 & 10 & 1 & 3,2 \\
\hline 5 & $\begin{array}{l}\text { Kami mengkoordinasikan semua fungsi } \\
\text { kami untuk memaksimalkan kepuasan } \\
\text { pelanggan }\end{array}$ & 0 & 1 & 4 & 11 & 14 & 3,93 \\
\hline
\end{tabular}

Tabel 4.2. Tanggapan Responden Atas Orientasi kewirausahaan

\begin{tabular}{|c|c|c|c|c|c|c|c|}
\hline \multirow{3}{*}{ No } & \multirow{3}{*}{ Pernyataan } & STS & $\mathrm{TS}$ & $\mathrm{N}$ & $S$ & SS & \multirow{3}{*}{$\begin{array}{l}\text { Rata-Rata } \\
\text { Jawaban }\end{array}$} \\
\hline & & \multicolumn{5}{|c|}{ BOBOT } & \\
\hline & & 1 & 2 & 3 & 4 & 5 & \\
\hline 1 & $\begin{array}{l}\text { Kami bersedia mengambil risiko besar } \\
\text { untuk mencapai pertumbuhan }\end{array}$ & 0 & 5 & 8 & 15 & 2 & 3,466 \\
\hline 2 & $\begin{array}{l}\text { Kami terus-menerus memperkenalkan } \\
\text { produk dan layanan baru untuk mencapai } \\
\text { pertumbuhan }\end{array}$ & 0 & 2 & 6 & 20 & 2 & 3,73 \\
\hline 3 & $\begin{array}{l}\text { Kami terus berusaha untuk tetap berada di } \\
\text { depan para pesaing kami untuk mencapai } \\
\text { pertumbuhan }\end{array}$ & 0 & 0 & 4 & 19 & 6 & 3,93 \\
\hline
\end{tabular}

Tabel 4.3. Tanggapan Responden Atas Kinerja Usaha 


\begin{tabular}{|l|l|c|c|c|c|c|c|c|}
\hline \multirow{2}{*}{ No } & \multicolumn{1}{|c|}{ Pernyataan } & STS & TS & N & S & SS & \multirow{2}{*}{$\begin{array}{c}\text { Rata-Rata } \\
\text { Jawaban }\end{array}$} \\
\cline { 3 - 7 } & \multicolumn{3}{|c|}{ BOBOT } \\
\cline { 3 - 6 } & & 1 & 2 & 3 & 4 & 5 & \\
\hline 2 & $\begin{array}{l}\text { Pengembangan penjualan kami lebih } \\
\text { baik dari tahun sebelumnya }\end{array}$ & 0 & 3 & 5 & 21 & 1 & 3,667 \\
\hline 3 & $\begin{array}{l}\text { Pengembangan profitabilitas kami telah } \\
\text { lebih baik dari tahun sebelumnya }\end{array}$ & 0 & 1 & 12 & 13 & 4 & 3,667 \\
\hline & $\begin{array}{l}\text { Toko kami secara finansial lebih sukses } \\
\text { dari tahun sebelumnya }\end{array}$ & 0 & 2 & 9 & 16 & 3 & 3,667 \\
\hline
\end{tabular}

Pada penelitian ini, sang peneliti menggunakan uji analisis data yang dilakukan dengan pengujian outer model yang terdiri dari 2 yaitu uji validitas dan reliabilitas serta pengujian inner model yang terdiri dari uji koefisien determinasi (R2), uji $Q$-square $\left(\mathrm{Q}^{2}\right)$, goodness of fit $(\mathrm{GoF})$, path coefficients dan juga hasil bootstrapping. Koefisien determinasi digunakan untuk mengetahui seberapa besar kontribusi variabel-variabel independen yang terdiri dari orientasi pasar, orientasi kewirausahaan untuk memprediksi variabel dependen pada penelitian ini yaitu Kinerja Usaha. Nilai Q-square dihasilkan melalui proses blinfolding yang terdapat dalam SmartPLS 3.0. metode blindfolding hanya diterapkan atau dilakukan pada variabel yang dipengaruhi menggunakan model pengukuran reflektif. Berdasarkan hasil pada 4.5, maka diketahui bahwa variabel Orientasi Pasar dan Orientasi Kewirausahaan memiliki pengaruh yang sedang terhadap Kinerja Usaha yaitu sebesar 0,263 . Sesuai dengan pendapat (Tenenhaus,2005) yang menyatakan bahwa nilai GoF dikatakan kecil apabila nilainya sebesar 0,1 dan dapat dikatakan sedang apabila nilainya sebesar 0,25 dan dinyatakan besar jika nilainya 0,36. Uji hipotesis pada penelitian ini digunakan untuk melihat hubungan antara variabel dalam penelitian ini dengan melihat hasil dari metode bootstrapping bagian $\mathrm{T}$ statistic dan $\mathrm{P}$ values. Jika Apabila nilai $\mathrm{T}$ statistic lebih besar dari 1,96 atau $\mathrm{P}$ values $<0,005$ maka $\mathrm{H} 0$ ditolak dan dapat dikatakan bahwa variabel independen $(\mathrm{X})$ berhubungan secara signifikan terhadap variabel dependen (Y).

Pengujian validitas dan reliabilitas data pada penelitian ini menggunakan hasil dari pengujian outer model yang sudah dilakukan dimana nilai outer loadings pada setiap indikator memiliki nilai yang lebih besar dari 0,5 dan nilai Average Variance Extracted (AVE) diatas 0,5 sehingga nilai discriminant validity dapat memenuhi kriteria. Hasil uji cronbach's alpha pada setiap variabel menghasilkan nilai diatas 0,6 dan hasil composite reliability pada setiap variabel meiliki nilai diatas 0,7 , sehingga data pada penelitian ini sudah reliabel karena sudah memenuhi kedua kriteria tersebut. Hasil pengujian analisis koefisen determinasi R2 pada penelitian ini adalah sebesar 0,524 atau 52\%.

Berdasarkan dari hasil koefisien determinasi R2 maka dapat diketahui bahwa orientasi pasar dan orientasi kewirausahaan memiliki pengaruh terhadap kinerja sebesar $52,4 \%$ dan dapat dikatakan koefisien determinasi R2 pada penelitian ini memiliki pengaruh yang lemah. Sedangkan 47,6\% kinerja dipengaruhi oleh variabel lain yang tidak terdapat dalam penelitian ini. Setelah melewati analisis koefisien determinasi R2 maka dilakukan Uji Q-square dengan metode blindfolding memiliki nilai 0,263 menunjukan bahwa variabel orientasi pasar dan orientasi kewirausahaan memiliki pengaruh yang kuat terhadap 
Kinerja usaha. Dan pengujian path coefficiens, hasil dari pengujian ini yaitu diperoleh persamaan dalam penelitian ini dengan $\mathrm{KU}=0,447 \mathrm{OP}+0,349 \mathrm{OK}$, dan mendapatkan hasil 0,563 menunjukan bahwa tingkat kelayakan model penelitian ini tergolong kuat. Berdasarkan persamaan tersebut dapat menunjukkan bahwa hubungan variabel orientasi kewirausahaan terhadap kinerja memiliki hubungan yang positif dan orientasi pasar berhubungan positif terhadap kinerja.

\section{DISKUSI}

Hasil dari pengujian hipotesis yang pertama menunjukkan bahwa orientasi pasar memiliki nilai t-statistik sebesar 2,190 yang berarti lebih besar dari pada batas nilai kriteria yaitu sebesar 1,96 dan nilai p-values orientasi pasar sebesar 0,014 yang berarti lebih kecil dari 0,05 atau $5 \%$. Sehingga melalui data diatas, dapat disimpulkan bahwa orientasi pasar berpengaruh terhadap kinerja Usaha Mikro Kecil dan Menengah. Hasil tersebut sejalan dengan penelitian Baker dan Sinkula (2009). Narver dan Slater (1990) yang menyatakan bahwa orientasi pasar memiliki pengaruh signifikan terhadap kinerja. Kemudian hipotesis yang kedua menunjukan bahwa pengujian orientasi kewirausahaan terbukti dapat berpengaruh secara signifikan terhadap kinerja Usaha Mikro Kecil dan Menengah dikarenakan hasil dari nilai t-statistik orientasi kewirausahaan sebesar 2,190 yang berarti lebih besar dari 1,96 dan p-values orientasi kewirausahaan sebesar 0,029 yang berarti lebih kecil dari 0,05 atau 5\%. Sehingga dapat diketahui bahwa orientasi kewirausahaan memiliki pengaruh yang signifikan terhadap kinerja Usaha Mikro Kecil dan Menengah. Berdasarkan dari hasil penelitian ini dapat diketahui bahwa $\mathrm{H} 2$ ditolak. Hal tersebut sesuai dengan penelitian yang telah dilakukan oleh Wiklund dan Shepherd (2005), Smart dan Conant (1994) dimana penelitian tersebut mengatakan bahwa orientasi kewirausahaan dan kinerja memiliki keterkaitan secara signifikan.

\section{PENUTUP}

Berdasarkan hasil analisa dan pembahasan yang telah dilakukan pada bab sebelumnya terhadap penelitian ini yang berjudul "pengaruh orientasi kewirausahaan yang signifikan terhadap kinerja Usaha Mikro Kecil dan Menengah pada Usaha Kuliner di Jelambar, Jakarta Barat.”, maka peneliti dapat memberikan beberapa saran yang dapat bermanfaat baik untuk penelitian selanjutnya maupun pihak pengusaha sebagai berikut:

a. Dari aspek orientasi pasar, peneliti menyarankan pemilik Usaha Mikro Kecil dan Menengah pada bidang usaha Kuliner untuk meningkatkan kepekaan dalam merespon pasar, mengetahui strategi yang dilakukan pesaing dengan tujuan agar usaha yang dijalani dapat beradaptasi dengan berbagai persaingan yang ada kedepannya.

b. Dari aspek orientasi kewirausahaan, peneliti menyarankan pemilik Usaha Mikro Kecil dan Menengah pada bidang usaha Kuliner untuk dapat menciptakan inovasi, proaktif serta dapat belajar mengambil resiko untuk keputusan yang sudah direncankan sehingga sekaligus dapat mempermudah proses adaptasi dalam lingkungan yang dinamis.

c. Untuk peneliti selanjutnya yang dilakukan, disarankan untuk menambah variabelvariabel lain di luar penelitian yang dimana memiliki kemungkinan untuk mempengaruhi kinerja usaha secara signifikan. 
d. Untuk peneliti selanjutnya, disarankan agar jangkauan area atau lokasi pengambilan sampel dan jumlah sampel yang akan diteliti dapat diperluas lagi dengan tujuan dapat memperkuat hasil dan melengkapi penelitian yang dilakukan sebelumnya.

\section{DAFTAR PUSTAKA}

Aritonang, R. L. (2007). Teori dan Praktik Riset Pemasaran. Bogor.

Day, G. S., \& Wensley, R. (1988). Assesing Advantage: A Framework for Diagnosing Competitive Superiority. Journal of Marketing , 1-20.

Idar, R., \& Mahmood, R. (2011). Entrepreneurial and Marketing Orientation Relationship to Performance:The SME Perspective. Interdisciplinary Review of Economics and Management 1

Jaworski, B., \& Kohli, A. (1993). Market Orientation: antecedents and consequences. Journal of Marketing , 53-71.

Knight, G. (2000). Entrepreneurship and marketing strategy: the SME under globalization. Journal of International Marketing , 12-32.

Kohli, A., \& Jaworski, B. (1990). Market Orientation: The Construct, Research Propositions, and Managerial Implications. Journal of Marketing, 54(2), 1-18

Narver, J., \& Slater, S. F. (1990). The Effect of a Market Orientation on Business Profitability. Journal of Marketing , 54(4), 20-35.

Ngo, L., \& O'Cass, A. (2012). performance implication of market orientation, marketing resources , and marketing capabilities. Journal of marketing management, 173-187.

Pelham, A. M., \& Wilson, D. T. (1996). A Longitudinal Study of the Impact of Market Structure, Firm Structure, Strategy, and Market Orientation Culture on Dimensions of Small-firm Performance." Journal of the Academy of Marketing Science, 24(1), 27-43.

Sugiyono. (2007). Metode Penelitian Kuantitatif Kualitatif dan R\&D. Bandung: Alfabeta.

Tenenhaus, M. V.-M. (2005). PLS path modeling. Computational Statistics \& Data Analysis, 159-205.

Utama, L. (2018). Pengaruh sumber daya pemilik waralaba terhadap kinerja penerima waralaba dengan orientasi kewirausahaan Sebagai mediasi.

Wiklund, J., \& Shepherd, D. (1999). The Sustainability of the Entrepreneurial Orientation Performance Relationship. Entrepreneurship Theory and Practice, 24(1), 37-48.

Zahra, S. A. (1991). Predictors and Financial Outcomes of Corporate Entrepreneurship: An Exploratory Study. Journal of Business Venturing, 6(4), 259-285. Doi: 10.1016/0833-9026(91)90019-A. 